\title{
7
}

\section{Identification of Molecules Involved in the Vulture Immune Sensing of Pathogens by Molecular Cloning}

\author{
Crespo, Elena ${ }^{1}$, de la Fuente, José ${ }^{1,2}$ and Pérez de la Lastra, José M. ${ }^{1}$ \\ IInstituto de Investigación en Recursos Cinegéticos (UCLM-CSIC-JCCLM), Ronda Toledo \\ 2Department of Veterinary Pathobiology, Center for Veterinary Health Sciences, \\ Oklahoma State University, Stillwater \\ ${ }^{1}$ Spain \\ ${ }^{2}$ USA
}

\section{Introduction}

Vultures may have one of the strongest immune systems of all vertebrates (Apanius et al., 1983; Ohishi et al., 1979). Vultures are unique vertebrates able to efficiently utilize carcass from other animals as a food resource. These carrion birds are in permanent contact with numerous pathogens and toxins found in its food. In addition, vultures tend to feed in large groups, because carcasses are patchy in space and time, and feeding often incurs fighting and wounding, exposing vultures to the penetration of microorganisms present in the carrion (Houston \& Cooper, 1975). Therefore, vultures were predicted to have evolved immune mechanisms to cope with a high risk of infection with virulent parasites.

Despite the potential interest in carrion bird immune system, little is known about the molecular mechanisms involved in the regulation of this process in vultures. The aim of this chapter is to describe the molecular cloning and characterization of two key molecules involved in the immune sensing of pathogens: a griffon vulture (Gyps fulvus) orthologue of TLR1 (CD281) and an orthologue of the alpha inhibitor of NF-kB (IкBa).

The toll-like receptor (TLR) family is an ancient pattern recognition receptor family, conserved from insects to mammals. Members of the TLR family are vital to immune function through the sensing of pathogenic agents and initiation of an appropriate immune response (Takeda \& Akira, 2005). The rapid identification of Toll orthologues in invertebrates and mammals suggests that these genes must be present in other vertebrates (Takeda, 2005). During the recent years, members of the multigene family of Toll-like receptors (TLRs) have been recognised as key players in the recognition of microbes during host defence (Hopkinsn \& Sriskandan, 2005). Recognition of pathogens by immune receptors leads to activation of macrophages, dendritic cells, and lymphocytes. Signals are then communicated to enhance expression of target molecules such as cytokines and adhesion molecules, depending on activation of various inducible transcription factors, among which the family NF-kappaB transcription factors plays a critical role. The involvement of NF-kB in the expression of numerous cytokines and adhesion molecules has supported its role as an evolutionarily conserved coordinating element in organism's response to situations of infection, stress, and 
injury. In many species, pathogen recognition, whether mediated via the Toll-like receptors or via the antigen-specific $\mathrm{T}$ - and B-cell receptors, initiates the activation of distinct signal transduction pathways that activate nuclear factor-kappa B (NF-KB) (Ghosh et al., 1998). TLRmediated NF- $\mathrm{KB}$ activation is also an evolutionarily conserved event that occurs in phylogenetically distinct species ranging from insects to mammals.

The identification of orthologues of TLRs in other species, particularly in those showing a strong immune system, together with the elucidation of their TLR-mediated signal transduction pathways, would contribute to our understanding of how these receptors have evolved and the importance of different orthologues to resistance to different pathogens.

\section{Strategy for cloning of vulture TLR1 and IKBa}

In order to identify key components of the vulture system for sensing of pathogens, we constructed and screened a cDNA library from vulture peripheral blood monuclear cells (PBMC) using specific probes for TLR1 and IKBa. Since the majority of toll-like receptors are expressed in leukocytes and lymphoid tissues in human and other vertebrates, we decided to use vulture PBMC as the source of RNA to obtain a specific probes for TLR1 and IkBa and to construct a cDNA library. Using this strategy we cloned cDNAs encoding for griffon vulture (Gyps fulvus) orthologues of mammalian TLR1 (CD281) and for the alpha inhibitor of NF-kB (IKBa). The tissue and cell expression pattern of vulture TLR1 and IкBa were analyzed by real-time RT-PCR and correlated with the ability to respond to various pathogenic challenges.

\subsection{Design of specific probes for vulture TLR1 and IKBa}

To obtain specific probes for vulture TLR1 and IKBa, total RNA was isolated from vulture PBMC and from cells and tissues using the Ultraspec isolation reagent (Biotecx Laboratories, Houston TX, USA). Ten micrograms of total RNA was heated at $65^{\circ} \mathrm{C}$ for 5 min, quenched on ice for $5 \mathrm{~min}$ and subjected to first strand cDNA synthesis. The RNA was reverse transcribed using an oligo dT12 primer by incubation with $200 \mathrm{U}$ RNase H- reverse transcriptase (Invitrogen, Barcelona, Spain) at $25^{\circ} \mathrm{C}$ for $10 \mathrm{~min}$, then at $42^{\circ} \mathrm{C}$ for $90 \mathrm{~min}$ in the presence of $50 \mathrm{mM}$ Tris- $\mathrm{HCl}, 75 \mathrm{mM} \mathrm{KCl}, 3 \mathrm{mM} \mathrm{MgCl}$, $10 \mathrm{mM}$ DTT, $30 \mathrm{U}$ RNase-inhibitor and $1 \mathrm{mM}$ dNTPs, in a total volume of $20 \mu \mathrm{l}$.

For the vulture TLR probe, a partial fragment of $567 \mathrm{bp}$ showing sequence similarity to human TLR-1 was amplified by PCR from vulture PBMC cDNA using two oligonucleotide primers TLR1/2Fw (5'-GAT TTC TTC CAG AGC TG-3') and TLR1/3Rv (5'-CAA AGA TGG ACT TGT AAC TCT TCT CAA TG $-3^{\prime}$ ), which were designed based on regions of high homology among the sequences of human and mouse TLR1 (GenBank, accession numbers NM_003263 and NM_030682, respectively). Cycling conditions were $94^{\circ} \mathrm{C}$ for $30 \mathrm{~s}, 52^{\circ} \mathrm{C}$ for $30 \mathrm{~s}$ and $72^{\circ} \mathrm{C}$ for $1.5 \mathrm{~min}$, for 30 cycles.

For the vulture IкBa probe, a partial fragment of $336 \mathrm{bp}$ showing sequence similarity to human and chicken IKBa was amplified by PCR from vulture PBMC cDNA using two oligonucleotide primers IkBa-Fw (5'-CCT GAA CTT CCA GAA CAA C-3') and IкBa-Rv (5'GAT GTA AAT GCT CAG GAG CCA TG-3'), which were designed based on regions of high homology among the sequences of human and chicken IKBa (GenBank, accession numbers 
M69043 and S55765, respectively). Cycling conditions were $94^{\circ} \mathrm{C}$ for $30 \mathrm{~s}, 52^{\circ} \mathrm{C}$ for $30 \mathrm{~s}$ and $72^{\circ} \mathrm{C}$ for $1.5 \mathrm{~min}$, for 30 cycles.

The obtained PCR products were cloned into pGEM-T easy vector using a TA cloning kit (Promega, Barcelona, Spain) and sequenced bidirectionally to confirm their respective specificities. These fragments were DIG-labelled following the recommendation of the manufacturer (Roche, Barcelona, Spain) and used as probes to screen 500000 plaque colonies of the vulture-PBMC cDNA library.

\section{2 cDNA library construction and screening}

Total RNA $(500 \mu \mathrm{g})$ was extracted from PBMC (pooled from 6 birds) using the Ultraspec isolation reagent (Biotecx). mRNA $(20 \mu \mathrm{g})$ was extracted by Dynabeads (Dynal biotechInvitrogen, Barcelona, Spain) and used in the construction of a cDNA library in Lambda ZAP vector (Stratagene, La Jolla, CA, USA) by directional cloning into EcoRI and XhoI sites. The cDNA library was plated by standard protocols at 50000 plaque forming units (pfu) per plate and grown on a lawn of XL1-Blue E. coli for 6-8 h. Screening of the library was performed with DIG labelled probes. Plaques were transferred onto Hybond-N+ membranes (Amersham, Barcelona, Spain) denatured in $1.5 \mathrm{M} \mathrm{NaCl} / 0.5 \mathrm{M} \mathrm{NaOH}$, neutralised in $1.5 \mathrm{M} \mathrm{NaCl} / 0.5$ Tris $(\mathrm{pH}$ 8.0) and fixed using a cross-linker oven (Stratagene). The filters were then pre-incubated with hybridisation buffer (5XSSC [1XSSC is $150 \mathrm{mM} \mathrm{NaCl}, 15 \mathrm{mM}$ trisodium citrate, $\mathrm{pH}$ 7.7], $0.1 \%$ N-laurylsarcosine, $0.02 \%$ SDS and $1 \%$ blocking reagent (Roche)) at $65^{\circ} \mathrm{C}$ for $1 \mathrm{~h}$ and then hybridised with hybridisation buffer containing the DIG-labelled probe, overnight at $65^{\circ} \mathrm{C}$. The membranes were washed at high stringency (2XSSC, $0.1 \%$ SDS; $2 \times 5$ min at ambient temperature followed by $0.5 \mathrm{XSSC}, 0.1 \% \mathrm{SDS} ; 2 \times 15 \mathrm{~min}$ at $\left.65^{\circ} \mathrm{C}\right)$. DiG-labelled probes were detected using phosphatase-labelled anti-digoxygenin antibodies (Roche) according to the manufacturer's instructions. Positive plaques on membranes were identified, isolated in agar plugs, eluted in $1 \mathrm{ml}$ of SM buffer $(0.1 \mathrm{M} \mathrm{NaCl}, 10 \mathrm{mM} \mathrm{MgSO} 4,0.01 \%$ gelatin, $50 \mathrm{mM}$ Tris-Hcl, $\mathrm{pH} 7.5$ ) for $24 \mathrm{~h}$ at $4^{\circ} \mathrm{C}$ and replated. The above screening protocol was then repeated. Individual positive plaques from the secondary screening were isolated in agar plugs and eluted in SM buffer. The cDNA inserts were recovered using the Exassist/SOLR system (Stratagene). Individual bacterial colonies containing phagemid were grown up in $\mathrm{LB}$ broth $(1 \% \mathrm{NaCl}, 1 \%$ trytone, $0.5 \%$ yeast extract, $\mathrm{pH} 7.0)$ containing $50 \mu \mathrm{g} / \mathrm{ml}$ ampicillin. Phagemid DNA was purified using a Bio-Rad plasmid mini-prep kit and sequenced.

\section{Structural analysis of vulture TLR1 and IKBa sequences}

Sequences were analyzed using the analysis software LaserGene (DNAstar, London, UK) and the analysis tools provided at the expasy web site (http://www.expasy.org). PEST regions are sequences rich in Pro, Glu, Asp, Ser and Thr, which have been proposed to constitute protein instability determinants. The analysis of the PEST region for the putative protein was made using the webtool PESTfind at http://www.at.embnet.org/ toolbox/pestfind. The potential phosphorylation sites were calculated using the NetPhos 2.0 prediction server at http://www.cbs.dtu.dk/services/NetPhos. The prediction of the potential attachment of small ubiquitin-related modifier (SUMO) was made using the webtool SUMOplot ${ }^{\mathrm{TM}}$. 
The alignment of vulture TIR domain sequences with TLR-1 from other species and of the vulture IкBa sequences with IкBa from other species was done using the program ClustalW v1.83 with Blosum62 as the scoring matrix and gap opening penalty of 1.53 . Griffon vulture TLR-1 and IKBa sequences were deposited in the Genbank under accession numbers DQ480086 and EU161944, respectively.

\subsection{Vulture TLR1}

The screening of the vulture PBMC cDNA library for TLR1 yielded seven clones with identical open reading frame (ORF) sequences. The fact that the screening of 500,000 vulture cDNA clones resulted in 7 identical sequences suggested that this TLR receptor is broadly represented in PBMC, possibly illustrating its important role in pathogen recognition during vulture innate immune response. This result was consistent with the real time RT-PCR analysis of TLR1 transcripts in vulture cells.

The largest clone $(2,355 \mathrm{bp})$ contained an ORF that encoded a 650 amino acid putative vulture orthologue to TLR1, flanked by $319 \mathrm{bp} 55^{\prime} \mathrm{UTR}$ and a $83 \mathrm{bp}$ 3'UTR that contained a potential polyadenylation signal, AATAAA, $21 \mathrm{bp}$ upstream of the poly (A) tail (Fig. 1). The predicted molecular weight of the putative vulture TLR1 was of 74.6 KDa. The predicted protein sequence had a signal peptide, an extracellular portion, a short transmembrane region and a cytoplasmic segment (Fig. 1). In assigning names to the vulture TLR, we looked at the closest orthologue in chicken and followed the nomenclature that was proposed for this species (Yilmaz et al., 2005). Therefore, the discovered sequence was identified as vulture TLR1.

\subsubsection{Amino acid sequence comparison of vulture TLR1 with other species}

The comparison of the deduced amino acid sequence of vulture TLR1 with the sequence of chicken, pig, cattle, human and mouse TLR1 indicated that the deduced protein had a higher degree of similarity to chicken ( $64 \%$ of amino acid similarity) than to pig (51\%), cattle $(51 \%)$, human $(51 \%)$ and mouse (48\%) sequences (Fig. 2). Protein sequence similarity was different on different TLR domains (Fig. 2).

Amino acid sequence of vulture TLR1 was aligned with the orthologous sequence of chicken (Gallus gallus), pig (Sus scrofa), cattle (Bos taurus), human (Homo sapiens) and mouse (Mus musculus) based on amino acid identity and structural similarity. Identical amino acid residues to vulture TLR1 from the aligned sequences are shaded. Gaps were introduced for optimal alignment of the sequences and are indicated by dashes (-). GenBank or Swiss protein accession numbers are: DQ480086, Q5WA51, Q59HI9, Q706D2, Q5FWG5 and Q6A0E8, respectively.

For the TLRs, it is assumed that the structure of the ectodomain has evolved more quickly than the structure of the TIR (Johnson et al., 2003). Similarly to other TLR receptors, the degree of homology of vulture TLR1 was higher in the transmembrane and cytoplasmic domains than in the extracellular domain.

The vulture TLR1 with 650 amino acids is probably the TLR with the shortest length and the smallest predicted MW (74.6 kDa). Recently, a chicken isoform of TLR1 (Ch-TLR1 type 2) was identified in silico and predicted to have a similar number of residues than vulture TLR1 (Yilmaz et al., 2005). However, this receptor also contains an additional transmembrane region in its $\mathrm{N}$-terminal end, and the pattern of expression in tissues is also different from that ChTLR1 type 1 (Yilmaz et al., 2005). 
cccagttctcagaagcatgcttcacaaatacggatcatactatgtgacttacacgcttatc aggcaaaagtctctgaagttcccataaaggatattctgaagaaagtttgaaggtactca taataatttgactgaatgccaggatataggaaggagaaagaaattaagcacatgtgga agaattgtatccttcttcacctagtccctggatattgatgaaattttgtcctaagaaga aataacgacttgaaggattagaacaaggtggacagataagagaagtattgagcatctcc aaggaaacagaaaccagtatgacagaaatatgagatctctcagaaactttttctttac $\begin{array}{lllllllllllllll}M & T & E & N & M & R & S & L & R & N & F & F & L & Y\end{array}$ aagtgtctgtttgcattaactttttggaattgtgtcagcctgtctgtggaaaatgaactc $\begin{array}{llllllllllllllllllllllllll}K & C & L & F & A & L & T & F & W & N & C & V & S & L & S & V & E & N & E & L\end{array}$ ttcacatctgtttctaacgaagatggttctgacaaaaaatcaagagcctgccactcctc

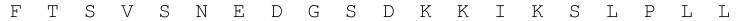
tatacaatagtcatcagtccaaagctaattttgactgggttgtgatacaaatactaca $\begin{array}{lllllllllllllllllllllllllll} & Y & T & N & S & H & Q & S & K & A & N & F & D & W & V & V & I & Q & \text { N } & T & T\end{array}$ gaaagcctatcgttgtcagaaatcacaaatgacaatgtaaaaaattagtagcattatta $\begin{array}{llllllllllllllllllll}E & S & L & S & L & S & E & I & T & N & D & N & V & K & K & L & V & A & L & L\end{array}$ tctaattcagacaaggctccaggttacaaatctgacactgacaaatgtgtcagttgac $\begin{array}{llllllllllllllllllllllll}S & N & F & R & Q & G & S & R & L & Q & \text { (N) } & L & T & L & T & \text { (N) } & V & S & V & D\end{array}$ tggaatgctcttattgaaactttcagactgtatggcactcacccattgaatacttcagt

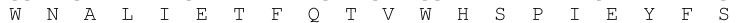
gttaacggtgtaacacaattgtcggacatcgaaagctatgactttgactattcaggtacg $\begin{array}{llllllllllllllllllll}V & N & G & V & T & Q & L & S & D & I & E & S & Y & D & F & D & Y & S & G & T\end{array}$ tctatgaaagcggtcacaatgaagaaagttttaatcacagatctgtacttctcacagaat $\begin{array}{lllllllllllllllllllll}S & M & K & A & V & T & M & K & K & V & L & I & T & D & L & Y & F & S & Q & N\end{array}$ gacctatacaaatatttgcagacatgaatattgcagccttgacaatagctgaatcagag $\begin{array}{llllllllllllllllllll}D & L & Y & K & I & F & A & D & M & N & I & A & A & L & T & I & A & E & S & E\end{array}$ atgatacatatgctgtgtccttcgtctgacagtcccttagatacttaaatttttaaag $\begin{array}{llllllllllllllllllll}M & I & H & M & L & C & P & S & S & D & S & P & F & R & Y & L & N & F & L & K\end{array}$ aacgatttaacagatctgcttttcaaaatgtgacaaattaattcaactggagacatta $\begin{array}{llllllllllllllllllll}N & D & L & T & D & L & L & F & Q & K & C & D & K & L & I & Q & L & E & T & L\end{array}$ atcttgccgaagaataaatttgagagccttccaaggtaagcttcatgactagccgtatg $\begin{array}{llllllllllllllllllll}I & L & P & K & N & K & F & E & S & L & S & K & V & S & F & M & T & S & R & M\end{array}$ aatcactgaaatacctggacatcagcagcaacttgctgagtcacgatggagctgatgtg $\begin{array}{lllllllllllllllllllll}K & S & L & K & Y & L & D & I & S & S & N & L & L & S & H & D & G & A & D & V\end{array}$ caatgccaatgggctgagtctctgacagagttggacctgtcctcaaatcagttgacggat $\begin{array}{llllllllllllllllllll}\text { Q } & C & Q & W & A & E & S & L & T & E & L & D & L & S & S & N & Q & L & T & D\end{array}$ gccgtgtttgagtgcttgccagtcaacatcagaaaactcaacctccaaaacaatcacatc $\begin{array}{lllllllllllllllllllll}A & V & F & E & C & L & P & V & N & I & R & K & L & N & L & Q & N & N & H & I\end{array}$ accagtgtccccaagggaatggetgagctgaaatccttgaaagagctgaacctggcatcg $\begin{array}{llllllllllllllllllll}T & S & V & P & K & G & M & A & E & L & K & S & L & K & E & L & N & L & A & S\end{array}$ aacaggctggetgacctgccggggtgcagtggctttacgtcgetggagttcctgaacgta

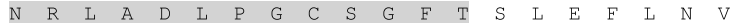
gagatgaattcgatcctcaccccatctgccgacttcttccagagctgcccacaggtcagg $\begin{array}{lllllllllllllllllllllllllllll}E & M & N & S & I & L & T & P & S & A & D & F & F & Q & S & C & P & Q & V & R\end{array}$ gagctgcaagccgggcacaacccattcaagtgttcctgtgaactgcaagactttatccgt $\begin{array}{llllllllllllllllllll}E & L & Q & A & G & H & N & P & F & K & C & S & C & E & L & Q & D & F & I & R\end{array}$ ctggcgaggcagtctggggggaagctgtttggctggccagcggcgtatgtgtgcgagtac $\begin{array}{llllllllllllllllllll}\text { L } & A & R & Q & S & G & G & K & \text { L } & F & G & W & P & A & A & Y & V & C & E & Y\end{array}$ ccggaagacttgcaaggaacgcagctgaaggacttccacctgactgaactggcttgcaac $\begin{array}{llllllllllllllllllll}P & E & D & L & Q & G & T & Q & L & K & D & F & H & L & T & E & L & A & C & N\end{array}$ acggtgctcttgctggtgacagctctgctgctgacgctggtgctggtggetgtcgtggec \begin{tabular}{llllllllllllllllllll} 
& $\mathrm{V}$ & $\mathrm{L}$ & $\mathrm{L}$ & $\mathrm{L}$ & $\mathrm{V}$ & $\mathrm{T}$ & $\mathrm{A}$ & $\mathrm{L}$ & $\mathrm{L}$ & $\mathrm{L}$ & $\mathrm{T}$ & $\mathrm{L}$ & $\mathrm{V}$ & $\mathrm{L}$ & $\mathrm{V}$ & $\mathrm{A}$ & $\mathrm{V}$ & $\mathrm{V}$ & $\mathrm{A}$ \\
\hline
\end{tabular} tttctgtgcatctacttggatgtgccgtggtacgtgcggatgacgtggcagtggacgcag

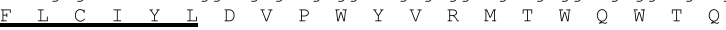
acaaagcggagggcttggcacagccaccccgaagagcaggagaccattctgcagtttcac $\begin{array}{lllllllllllllllllllllllllllll}T & K & R & R & A & W & H & S & H & P & E & E & Q & E & T & I & L & Q & F & H\end{array}$ gcgttcattcctacagcgagcgcgattcgttgtgggtgaagaacgagctgatcccgaac \begin{tabular}{|llllllllllllllllllll}
\hline A & F & I & S & $Y$ & S & E & R & D & S & L & W & V & K & N & E & L & I & P & N \\
\hline
\end{tabular} ctggagaagggggagggctgtgtacaactgtgccagcacgagaggaactttatccccggc \begin{tabular}{|llllllllllllllllllll}
\hline & $\mathrm{E}$ & $\mathrm{K}$ & $\mathrm{G}$ & $\mathrm{E}$ & $\mathrm{G}$ & $\mathrm{C}$ & $\mathrm{V}$ & $\mathrm{Q}$ & $\mathrm{L}$ & $\mathrm{C}$ & $\mathrm{Q}$ & $\mathrm{H}$ & $\mathrm{E}$ & $\mathrm{R}$ & $\mathrm{N}$ & $\mathrm{F}$ & $\mathrm{I}$ & $\mathrm{P}$ & $\mathrm{G}$ \\
\hline
\end{tabular} \begin{tabular}{lllllllllllllllllllll}
\hline$K$ & $S$ & $I$ & $V$ & $E$ & $N$ & $I$ & $I$ & $N$ & $C$ & $I$ & $E$ & $K$ & $S$ & $Y$ & $R$ & $S$ & $I$ & $F$ & $V$
\end{tabular} ttgtctcccaactttgtgcagagcgagtggtgtcactatgagctgtactttgcccatcac \begin{tabular}{|llllllllllllllllllll|}
\hline $\mathrm{L}$ & $\mathrm{S}$ & $\mathrm{P}$ & $\mathrm{N}$ & $\mathrm{F}$ & $\mathrm{V}$ & $\mathrm{Q}$ & $\mathrm{S}$ & $\mathrm{E}$ & $\mathrm{W}$ & $\mathrm{C}$ & $\mathrm{H}$ & $\mathrm{Y}$ & $\mathrm{E}$ & $\mathrm{L}$ & $\mathrm{Y}$ & $\mathrm{F}$ & $\mathrm{A}$ & $\mathrm{H}$ & $\mathrm{H}$ \\
\hline
\end{tabular} aattattcagtgagaattccaacagcttaatcctcattttactggagccgatccctccg \begin{tabular}{|llllllllllllllllllll}
\hline$K$ & $L$ & F & S & E & N & S & N & S & L & I & L & I & L & L & E & P & I & P & P \\
\hline
\end{tabular} tacattatccctgccaggtatcacaagctgaaggctctcatggcaaagcgaacctacctg \begin{tabular}{|lllllllllllllllllllll}
\hline & $I$ & $I$ & $P$ & $A$ & $R$ & $Y$ & $H$ & $K$ & L & K & A & L & M & A & K & R & T & Y & L
\end{tabular} gagtggccaaaggagaggagcaagcatcccctttctgggctaacctgagggcagctatt \begin{tabular}{|llllllllllllllllllll|}
\hline$E$ & $W$ & P & K & E & R & S & K & H & P & L & F & W & A & N & L & R & A & A & I \\
\hline
\end{tabular} agcattaacctgctaatggctgatggaaagaggtgtggggaaacagattaagaatcttc \begin{tabular}{lllllllllllllllll}
\hline$S$ & $I$ & $N$ & $L$ & $L$ & $M$ & $A$ & $D$ & $G$ & $K$ & $R$ & $C$ & $G$ & $E$ & $T$ & $D$ & $*$
\end{tabular} taatggagtttcttccatttttcttggtgaagcaataaatgctttatgatttccaaaa

61 121

Fig. 1. Nucleotide and deduced amino acid sequence of vulture TLR1. Complete sequence of the full-length Vulture TLR obtained from the cDNA library (GenBank accession number: 
DQ480086). Translated amino acid sequence is also shown under nucleotide sequence. Numbers to the right of each row refer to nucleotide or amino acid position. The cleavage site for the putative signal peptide is indicated by an arrow. LRRs domains are shaded. Potential N-glycosylation sites are circled. The predicted transmembrane segment is underlined. The initiation codon (atg) and the polyadenilation site are underlined. The translational stop site is indicated by an asterisk. The cysteines critical for the maintenance of the structure of LRR-CT are in bold.

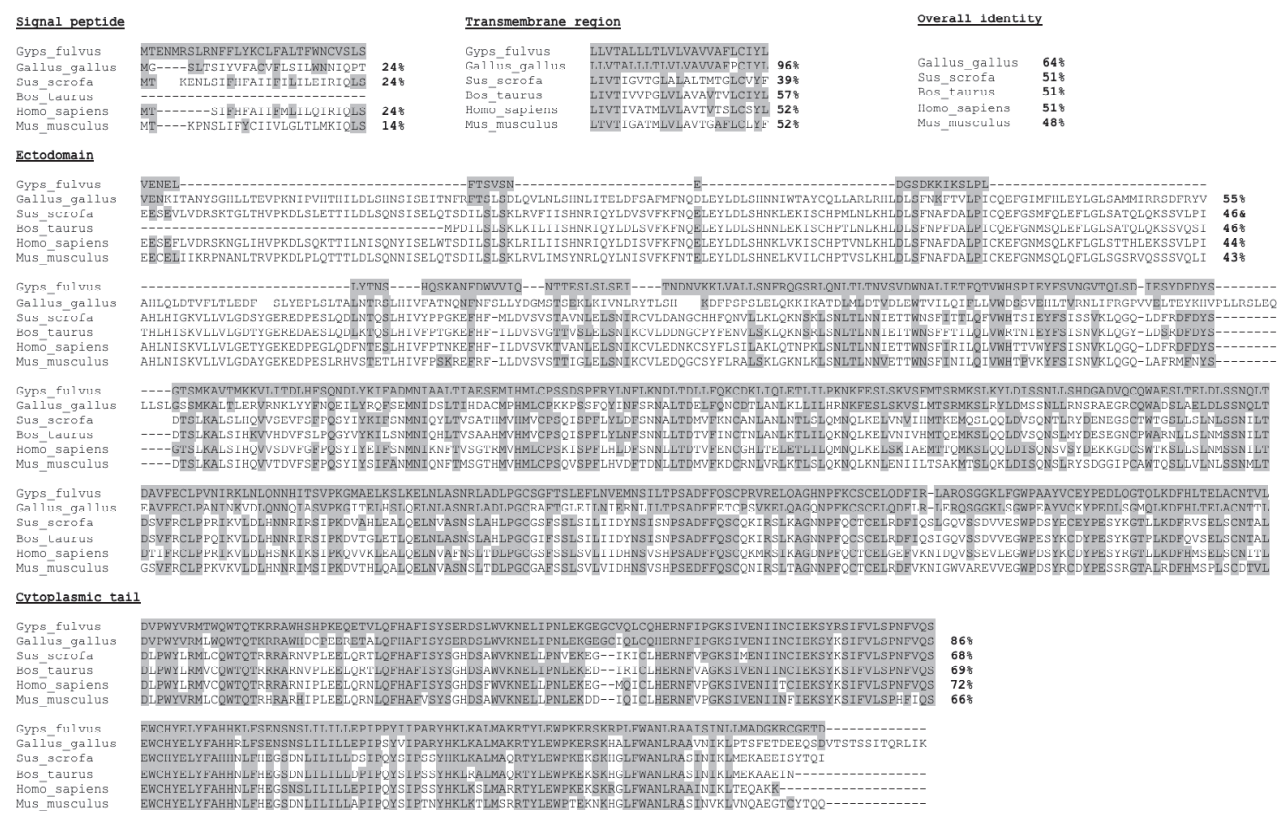

Fig. 2. Alignment of amino acid sequences of TLR1 from different species. 

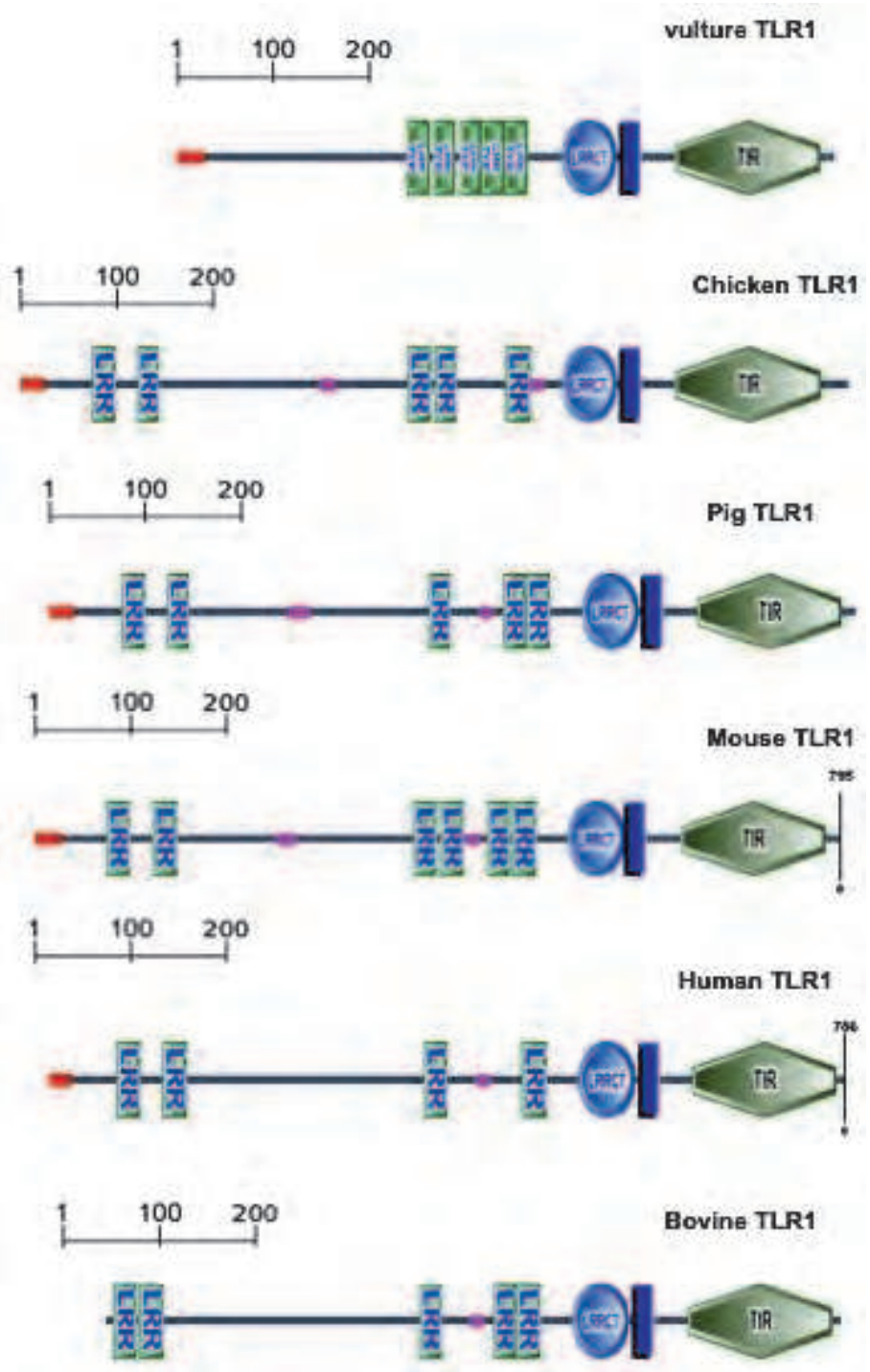

Fig. 3. Schematic structure of TLR1 from various species

Comparison of the structure obtained from the SMART analysis (at expasy web server) of the amino acid sequence from human, bovine, pig, mouse, chicken and vulture TLR1. Each diagram shows a typical structure of a member of the toll-like receptor family. Vulture TLR1 consists of an ectodomain containing five leucine rich repeats (LRRs) followed by an additional leucine rich repeat $C$ terminal (LRR-CT) motif. The Vulture TLR has a transmembrane segment and a cytoplasmic tail which contains the TIR domain. Genbank or swiss accession number for proteins are DQ480086 (vulture), Q5WA51 (chicken), Q59HI9 (pig), Q706D2 (bovine), Q5FWG5 (human) and Q6A0E8 (mouse). 
In general, the structure of vulture TLR1 shows similarity to chicken and mammalian TLR1 (Table 1). However, vulture TLR1 exhibits some structural features that could influence its functional role as pathogen receptor (Fig. 3). For example, it is possible that the smaller size of vulture TLR1, the lower number of N-glycosylation sites and the grouping of its LRRs in the proximal half of its ectodomain have functional implications.

\begin{tabular}{lcccccc}
\multicolumn{1}{c}{ Structural feature } & G fulvus & G gallus & S scrofa & B taurus & H sapiens & M musculus \\
\hline $\begin{array}{l}\text { Amino acid residues } \\
\text { Number of LRRs }\end{array}$ & 650 & 818 & 796 & 727 & 786 & 795 \\
$\begin{array}{l}\text { N-glycosylation } \\
\text { sites }\end{array}$ & 5 & 5 & 5 & 5 & 4 & 6 \\
$\begin{array}{l}\text { Predicted MW(KDa) } \\
\text { Length of }\end{array}$ & 74.60 & 94.46 & 90.94 & 83.04 & 90.29 & 90.67 \\
ectodomain & 409 & 569 & 560 & 521 & 560 & 558 \\
\hline
\end{tabular}

Table 1. Structural features of TLR1 receptor from Griffon vulture (G fulvus), Chicken (G gallus), pig (S scrofa), cattle (B Taurus) human (H sapiens) and mouse (M musculus) amino acid sequences. The theoretical molecular weight, number of LRRs, and of glycosilation sites was calculated using the software available at the expasy web server (http:/ / www.expasy.org). Genbank or Swiss accession number for proteins are DQ480086 (G fulvus), Q5WA51 (G gallus), Q59HI9 (S scrofa), Q706D2 (B Taurus), Q5FWG5 (H sapiens) and Q6A0E8 (M musculus).

The set of Toll proteins for humans and insects each contain widely divergent LRR regions, and this is viewed as providing the potential to discriminate between different ligands. Perhaps these features provide vulture TLR1 some advantages on pathogen recognition. TLR glycosylation is also likely to influence receptor surface representation, trafficking and pattern recognition (Weber et al., 2004).

\subsection{Vulture IKBa}

The screening of the vulture PBMC cDNA library yielded one clone that contained an ORF that encoded a 313 amino acid putative vulture orthologue to IKBa, flanked by $15 \mathrm{bp} 5^{\prime} \mathrm{UTR}$ and a 596 bp 3’UTR (Fig. 4).

The predicted molecular weight of the putative vulture IкBa was of $35170 \mathrm{Da}$. Structurally, the vulture I kappa B alpha molecule could be divided into three sections: a 70-amino-acid $\mathrm{N}$ terminus with no known function, a 205-residue midsection composed of five ankyrinlike repeats, and a very acidic 42 -amino-acid $C$ terminus that resembles a PEST sequence. Examination of the Griffon vulture sequence revealed the features characteristic of an IкB molecule (Fig. 4) The putative vulture IkBa protein was composed of a N-terminal regulatory domain, a central ankyrin repeat domain (ARD), required for its interaction with NF-KB, and a putative PEST-like sequence in the C-terminus (Fig. 5), which is similar to IkBa proteins from other organisms (Jaffray et al., 1995). Together with the N-terminal regulatory domain and the central ARD domain, the presence of an acidic C-terminal PEST region rich in the amino acids proline $(\mathrm{P})$, glutamic acid $(\mathrm{E})$, serine $(\mathrm{S})$ and threonine $(\mathrm{T})$ is characteristic of IKBa inhibitors (Luque \& Gelinas, 1998). PEST regions have been found in the C-terminus of avian IKBa (Krishnan et al., 1995) and mammalian IKBa and it was also present in the vulture IкBa sequence (Fig. 5). Particularly, the PEST sequence of IкBa seems to be critical for its calpain-dependent degradation (Shumway et al., 1999). 
cggagccctgccgctatgatcagcgcccgccgcctcgtcgagccgccggttatggagggc

60 $\begin{array}{llllllllllllllll}M & I & S & A & R & R & L & V & E & P & P & V & M & E & G & 15\end{array}$

tacgagcaagcgaagaaagagcgccagggcggcttcccgctcgacgaccgccacgacagc 120

$\begin{array}{lllllllllllllllllllll}Y & E & Q & A & K & K & E & R & Q & G & G & F & P & L & D & D & R & H & D & S & \end{array}$

ggcttggactccatgaaggaggaagagtaccggcagctggtgaaggagctggaggacata 180

\begin{tabular}{lllllllllllllllllllll}
$G$ & $L$ & $D$ & $S$ & $M$ & $K$ & $E$ & $E$ & $E$ & $Y$ & $R$ & $Q$ & $L$ & $V$ & $K$ & $E$ & $L$ & $E$ & $D$ & $I$ & \\
\hline
\end{tabular}

cgcctgcagccccgcgagccgcccgcctgggcgcagcagctgacggaggacggagacact 240

$\begin{array}{lllllllllllllllllllll}R & L & Q & P & R & E & P & P & A & W & A & Q & Q & L & T & E & D & G & D & T & 75\end{array}$

tttctccacttggcgattattcacgaggaaaagccctgagcctggaggtgatccggcag 300

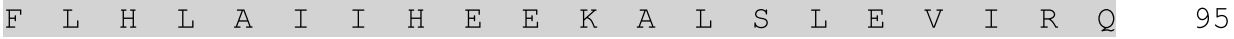

gcggccggggaccgtgctttcctgaacttccagaacaacctcagccagactcctcttcac 360

$\begin{array}{lllllllllllllllllllll}A & A & G & D & R & A & F & L & N & F & Q & N & N & L & S & Q & T & P & L & H & \\ 115\end{array}$

ctggcagtgatcaccgatcagcctgaaattgccgagcatcttctgaaggccggatgcgac 420

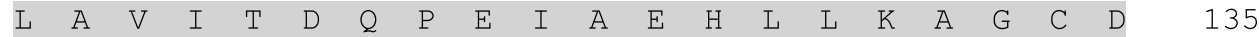

ctggaactcagggacttccgaggaaacacccccetgcatattgcctgccagcagggctcc 480

$\begin{array}{lllllllllllllllllllll}L & E & L & R & D & F & R & G & N & T & P & L & H & I & A & C & Q & Q & G & S & \\ 155\end{array}$

ctcaggagcgtcagcgtcctcacgcagtactgccagccgcaccacctcctcgctgtcctg 540

$\begin{array}{llllllllllllllllllllll}\text { L } & R & S & \text { V } & \text { S } & \text { V } & \text { L } & \text { T } & \text { Q } & \text { Y } & \text { C } & \text { Q } & \text { P } & \text { H } & \text { H } & \text { L } & \text { L } & \text { A } & \text { V } & \text { L } & & 175\end{array}$

caggcaaccaactacaacgggcatacatgtctccatttggcatctattcaaggatacctg 600

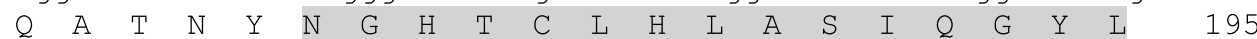

cctattgtcgaatacttgctgtccttgggagcagatgtaatgctcaggagccatgcaat $\quad 660$

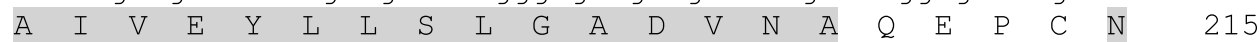

ggcagaacggcactacatttggctgtcgacctgcagaattcagacctggtgtcgcttctg 720

$\begin{array}{llllllllllllllllllllll}\text { G } & R & \text { T } & \text { A } & \text { L } & \text { H } & \text { L } & \text { A } & \text { V } & \text { D } & \text { L } & \text { Q } & \text { N } & \text { S } & \text { D } & \text { L } & \text { V } & \text { S } & \text { L } & \text { L } & 235\end{array}$

gtgaaacatggggcggacgtgaacaaagtgacctaccaaggctattccccctatcagctc 780

$\begin{array}{lllllllllllllllllllll}V & K & H & G & A & D & V & N & K & V & T & Y & Q & G & Y & S & P & Y & Q & L & 255\end{array}$

acatggggaagagacaactccagcatacaggaacagctgaagcagctgaccacagccgac 840

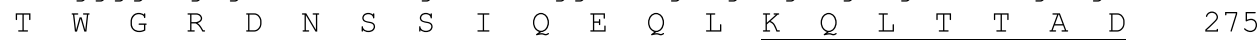

ctgcagatgttgccagaaagtgaggacgaggagagcagtgaatcggagcctgaattcaca 900

$\begin{array}{lllllllllllllllllllll}L & Q & M & L & P & E & S & E & D & E & E & S & S & E & S & E & P & E & F & T & 295\end{array}$

gaggatgaacttatatacgatgactgccttattggaggacgacagctggcattttaaagc $\quad 960$

$\begin{array}{llllllllllllllllllll}E & D & E & L & I & Y & D & D & C & L & I & G & G & R & Q & L & A & F & * & \end{array}$

agagctatctgtgaaagaagtgactgtgtacatatgtatagaaaaggactgacttcat $\quad 1020$

ttaaaagaaagtcgcaatgcaaagggaaaaccaggagggaaatactacactgcccagc $\quad 1080$

aaggagcacataattgtaacaggttctggcctgtgtttaaatacaggagtgggatgtgta 1140

acatcagtagggatctgtgattattcacaccacctgataaagagccacatagccaatctt 1200

ctcagccctacaaaggtaacagactacacatccaacctgctggttacagagagctatctt $\quad 1260$

gtggtgttaagtaccacgaggaatgcgtgtcgcctcgtggcaaggcaggctcataccaac 1320

ccccccatcttctcggagactgcgtgttaatctgcgttgggctggtggtgctccctggcc 1380

ttactgaccggcctcagctgctcttggtggggtgtcccaggtggaggagtcaaaccaagg 1440

gactggtgacctcctgactgttagaagaaagtagcaataatgttaactgtgggcattgga 1500

aactgtgtgtttcacaccatgtgtgtcataattgctacactttttagcaattg 1553

Fig. 4. Nucleotide and deduced amino acid sequence of vulture IкBa. Complete sequence of the full-length vulture IKBa obtained from the cDNA library (GenBank accession number: EU161944). Translated amino acid sequence is also shown under nucleotide sequence. Numbers to the right of each row refer to nucleotide or amino acid position. Ankyrin domains are shaded. The PEST region is underlined. The ATTTA domain is in bold. Phosphorylation sites Ser-35 and Ser-39 are circled. The translational stop site is indicated by an asterisk. 


\section{Regulatory domain}
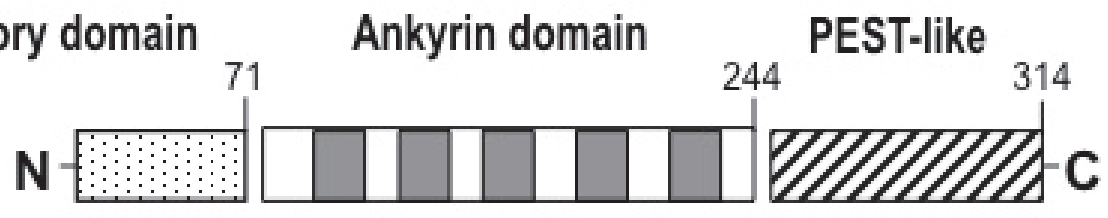

Fig. 5. Schematic structure of vulture ІкBa.

Structure obtained from the SMART analysis (at expasy web server) of the amino acid sequence from vulture IкBa. Each box shows a typical structure of a member of the IKBa inhibitor. Vulture IkBa consists of an N-terminus regulatory domain, a central ankyrin domain containing five ankyrin repeats followed by an additional PEST-like motif. Number shows the amino acid flanking the relevant domains.

Classical activation of NF-kappaB involves phosphorylation, polyubiquitination and subsequent degradation of ІкB. Several residues are known to be important in the Nterminal regulatory domain (Luque \& Gelinas, 1998, Luque et al., 2000). In nonstimulated cells, NF-kappa B dimers are maintained in the cytoplasm through interaction with inhibitory proteins, the IкBs. In response to cell stimulation, mainly by proinflammatory cytokines, a multisubunit protein kinase, the I kappa B kinase (IKK), is rapidly activated and phosphorylates two critical serines in the N-terminal regulatory domain of the I kappa Bs. Phosphorylated IкBs are recognized by a specific E3 ubiquitin ligase complex on neighboring lysine residues, which targets them for rapid degradation by the $26 \mathrm{~S}$ proteasome, which frees NF-kappaB and leads to its translocation to the nucleus, where it regulates gene transcription (Karin \& Ben-Neriah, 2000). It has been demonstrated that phosphorylation of the N-terminus residues Ser-32 and Ser-36 is the signal that leads to inducer-mediated degradation of IKBa in mammals (Brown et al., 1997; Good et al., 1996). As can be observed in the alignment of Figure 6, the griffon vulture equivalent residues seem to be Ser-35 and Ser-39, which are part of the conserved sequence DSGLDS (Luque et al., 2000; Pons et al., 2007). This observation suggests that the phosphorylation of these serine residues could trigger the IKBa inducer-mediated degradation in vulture in a similar manner to that in mammals. Unlike ubiquitin modification, which requires phosphorylation of S32 and S36, the small ubiquitin-like modifier (SUMO) modification of IKBa is inhibited by phosphorylation. Thus, while ubiquitination targets proteins for rapid degradation, SUMO modification acts antagonistically to generate proteins resistant to degradation (Desterro et al., 1998; Mabb \& Miyamoto, 2007). This SUMO modification occurs primarily on K21 (Mabb \& Miyamoto, 2007). This residue was also conserved in the IкBa sequence from human, mouse, pig, rat and vulture, but not from chicken (Fig. 6).

Amino acid sequence of vulture IkBa was aligned with the orthologous sequence of chicken (Gallus gallus), pig (Sus scrofa), cattle (Bos taurus), human (Homo sapiens) and mouse (Mus musculus) based on amino acid identity and structural similarity. Identical amino acid residues to vulture IкBa from the aligned sequences are shaded. Gaps were introduced for optimal alignment of the sequences and are indicated by dashes (-). SUMOlation sites are squared and phosphorylation sites are circled. GenBank or Swiss protein accession numbers are: DQ480086, Q5WA51, Q59HI9, Q706D2, Q5FWG5 and Q6A0E8, respectively. Griffon vulture IKBa sequence was deposited in the Genbank under accession number EU161944. 
Identification of Molecules Involved in the

Vulture Chicken

Human

Mouse

Pig

Rat

Vulture

Chicken

Human

Mouse

Pig

Rat

Vulture

Chicken

Human

Mouse

Pig

Rat

Vulture

Chicken

Human

Mouse

Pig

Rat

Vulture

Chicken

Human

Mouse

Pig

Rat

Vulture

Chicken

Human

Mouse

Pig

Rat
MI SARRLVEP PVMECYEQA-KKERQGGFPL-DDRHISGLDSDIKEEEYRQLVKELEDIRLQP MLSAHRPAEPPAVEGCEPP-RKERQGGLLPPDDRHLSGLDSD]KEEEYRQLVRELEDIRLQP MFQAAERPQEWAMEGPRDGITKER---LL--DDRHDSSLDSDIKPEEYI QMVKELQEIRLEP MFQPAGHGQDWAMEGPRDGI KKER---LV--DDRHLSGLDSDIKDERYEMVKELREIRLQP MFQPAEPGQEWAMEGPRDAI KRER---LL--DDRHD(SCLDDSIKDEYY)EQMVKELREIRLEP MFQPAGHGQDWAMEGPRDGILKER---LV--DDRHDSSLDSDIKDEIY)EQMVKELREIRLQP

\begin{abstract}
REPP----AWAQQLTEDGDTFLHLAI IHEEKAISSEVIRQAAGDRAFLNFQNNLSQTPLH REPPARPHAWAQQLTEDGDTFLHLAI I HEEKAISSEVIRQAAGDAAFLNFQNNLSQTPLH QEVPR@SEPWKQQLTEDGDSFLHLAI IHEEKALTMEVIRQVKGLAFLNFQNNLQQTPLH QEAPLAAEPWKQQLTEDGDSFLHLA I IHEEKPLTMEVIGQKGDLAFLNEQNNLQQTPLH QEAPRGAEPWKQQLTEDGDSFLHLAI I HEEKALTMEVVRQKGDLAFLNFQNNLQQTPLH QEAPLAAEPWKQQLTEDGDSFLHLAI I HEE(T)TMEVIGQVKDLAFLNFQNNLQQTPLH
\end{abstract}

\begin{abstract}
LAVITDQPEIAEHLIKAGCDLELRDFRGNTPLHIACQQGSLRSVSILTQYCQPHHLLAVI LAVITDQAE IAEHLIKA GCDLDVRDFRGNTPLHIACQQGSLPSSSVLTQHCQPHHLLAVL LAVITNQPEIAEALLGAGCDPELRDFRGNTPLHLACEQGCLASVGVITDSCTTPHLHSIL LAVITNQPGIAEALIKAGCDPELRDFRGNTPLHLACEQGCLASVAVLTQTCTPQHLHSVL LAVITNQPEIAEALLEAGCDPELRDFRGNTPLHLACEQGCLASVGVLTQPRGTQHLHSSL LAVITNQPGIAEALI KA GCDPELRDFRGNTPLHLACEQGCLASVAVLTQTCTPQHLHSVL
\end{abstract}

\begin{abstract}
QATNYNGHTCLHLAS IQGYLAIVEYLLSLGADVNAQEPCNGRTALHLAVDLQNSDLVSLL QATNYNGHTCLHLAS IQGYLAVVEYLLSLGADVNAQEPCNGRTALHLAVDLQNSDLVSLL KATNYNGHTCLHLAS I HGYLGIVELLVSLGADVNAQEPCNGRTALHLAVDLQNPDLVSLL QATNYNGHTCLHLAS I HGYLA IVEHLVTLGADVNAQEPCNGRTALHLAVDLQNPDLVSLL QATNYNGHTCLHLAS IHGYLGIVELLVSLGADVNAQEPCNGRTALHLAVDLQNPDLVSLL QATNYNGHTCLHLAS I HGYLGIVEHLVTLGADVNAQEPCNGRTALHLAVDLQNPDLVSLL
\end{abstract}

Fig. 6. Alignment of amino acid sequences of IкBa from different species.

$\begin{array}{lr}\text { Overall } & \text { identity } \\ \text { Chicken } & 91 \% \\ \text { Human } & 73 \% \\ \text { Mouse } & 74 \% \\ \text { Pig } & 73 \% \\ \text { Rat } & 73 \%\end{array}$

Pig

$73 \frac{0}{0}$

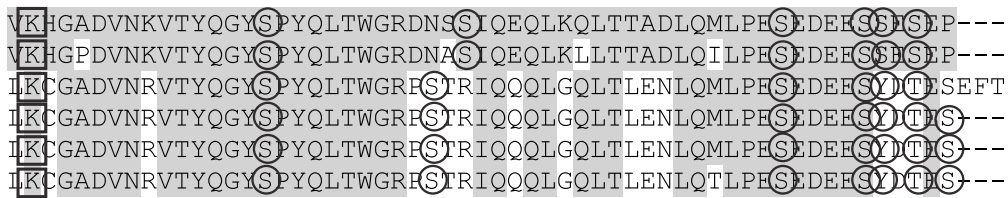

EFTIDELIYDDCLIGGRQLAF EF(T)DELMYDCCI GGRQLTF EF(T)DELPYDCVFGGQRLTL EF(T)DELYYDDCVFGGQRLTL EF(TLDELPODCVLGGQRLTL EF(T)DELYYDDCVFGGQRLTL

wwwintechopen.com 
A common characteristic of the IKB proteins is the presence of ankyrin repeats, which interact with the Rel-homology domain of NF-kB (Aoki et al., 1996; Luque \& Gelinas, 1998). In the vulture sequence, five ankyrin repeats were detected using the Simple Modular Architecture Research Tool (SMART) at EMBL (Table 2). Five ankyrin repeats also exist in human and other vertebrates IкBa (Jaffray et al., 1995). It is possible that individual repeats have remained conserved because of their important structural and functional roles in regulating NF-KB.

Compared with other species, vulture IкBa exhibited the lowest number of predicted SUMOlation sites (Table 2).

\begin{tabular}{|c|c|c|c|c|c|c|}
\hline Structural feature & $\begin{array}{c}G \\
\text { fulvus }\end{array}$ & $\begin{array}{c}G \\
\text { gallus }\end{array}$ & H sapiens & $\begin{array}{c}S \\
\text { scrofa }\end{array}$ & $\begin{array}{c}R \\
\text { norvegicus }\end{array}$ & $\begin{array}{c}\text { M } \\
\text { musculus }\end{array}$ \\
\hline Amino acid residues & 313 & 318 & 317 & 314 & 314 & 314 \\
\hline $\begin{array}{l}\text { Number of ankyrin } \\
\text { repeats }\end{array}$ & 5 & 5 & 5 & 5 & 5 & 5 \\
\hline Phosphorylation sites & 14 & 13 & 14 & 15 & 14 & 13 \\
\hline Predicted MW(KDa) & 35,17 & 35,40 & 35,61 & 35,23 & 35,02 & 35,02 \\
\hline SUMOlation sites & 2 & 3 & 4 & 4 & 5 & 5 \\
\hline
\end{tabular}

Table 2. Structural features of IkBa from Griffon vulture (G fulvus), Chicken (G gallus), human (H sapiens), pig (S scrofa), rat (R norvegicus) and mouse (M musculus) amino acid sequences. The theoretical molecular weight, number of ankyrin repeats, SUMOlation and of phosphorylation sites was calculated using the software available at the expasy web server (http:/ / www.expasy.org). Genbank or Swiss accession number for proteins are EU161944 (G fulvus), Q91974 (G gallus), P25963 (H sapiens), Q08353 (S scrofa), Q63746 (R norvegicus), and Q9Z1E3 (M musculus).

\subsubsection{Amino acid sequence comparison of vulture IKBa with other species}

The comparison of the deduced amino acid sequence of vulture IkBa with the sequence of chicken, human, mouse, pig, and rat IKBa indicated that the deduced protein had a higher degree of similarity to chicken (91\% of amino acid similarity) than to human (73\%), mouse $(74 \%)$, pig $(73 \%)$ and rat (73\%) sequences (Fig. 6). The analysis of the vulture IKBa sequence using the software NetPhos 2.0 (http://www.cbs.dtu.dk/services/NetPhos) revealed 14 potential phosphorylation sites: 10 Ser (S35, S39, S89, S160, S251, S263, S282, S287, S288, and S290), 1 Thr (T295) and 3 Tyr (Y16, Y45, and Y301). Although many of these residues were conserved in the aligned sequences from chicken, human, mouse, pig and rat IkBa, two phosphorylation sites (Y16 and S160) were distinctive to the vulture sequence (Fig. 6).

\section{Detection of vulture TLR1 and IKBa expression in tissues}

In order to better understand the biological roles of TLR1 and ІкBa, we analyzed their tissue expression pattern. The presence of transcripts encoding vulture TLR1 and IkBa in tissues was determined by real time RT-PCR. Biological samples were collected from vultures (about 8-10 months old) that were provisionally captive at the Centre for Wild Life Protection, "El Chaparrillo", Ciudad Real, Spain. Blood was obtained by puncture of the branquial vein, located in the internal face of the wing, and collected in $10 \mathrm{ml}$ tubes with EDTA as anti-coagulant. Blood $(10 \mathrm{ml})$ was diluted 1:1 (vol:vol) with PBS (Sigma) and the 
mononuclear fraction containing PBMC was obtained by density gradient centrifugation on Lymphoprep (Axis-Shield, Oslo, Norway). All vulture tissues used for cDNA preparation were obtained fresh from euthanised birds that were impossible to recover.

RT-PCR was performed on a SmartCycler ${ }^{\circledR}$ II thermal cycler (Cepheid, Sunnyvale, CA, USA) using the QuantiTect ${ }^{\circledR}$ SYBR ${ }^{\circledR}$ Green RT-PCR Kit (Quiagen, Valencia, CA, USA), following the recommendations of the manufacturer. We used primers GfTLR-Fw (5'-GCT TGC CAG TCA ACA TCA GA-3') and GfTLR-Rv (5'-GAA CTC CAG CGA CGT AAA GC$\left.3^{\prime}\right)$, which amplify a fragment of 158 bp of vulture TLR1 and primers IkBa -L (5'- CTG CAG GCA ACC AAC TAC AA -3') and IkBa -R (5'- TGA ATT CTG CAG GTC GAC AG-3'), which amplify a fragment of $165 \mathrm{~b}$ of vulture IKBa. Cycling conditions were: $94^{\circ} \mathrm{C}$ for $30 \mathrm{sec}$, $60^{\circ} \mathrm{C}$ for $30 \mathrm{sec}, 72^{\circ} \mathrm{C}$ for $1 \mathrm{~min}$, for 40 cycles. As an internal control, RT-PCR was performed on the same RNAs using the primers BA-Fw (5'-CTA TCC AGG CTG TGC TGT CC-3') and BA-Rv (5'-TGA GGT AGT CTG TCA GGT CAG G-3'), which amplify a fragment of $165 \mathrm{bp}$ from the conserved housekeeping gene beta-actin. Control reactions were done using the same procedures, but without RT to control for DNA contamination in the RNA preparations, and without RNA added to control contamination of the PCR reaction. Amplification efficiencies were validated and normalized against vulture beta actin, (GenBank accession number DQ507221) using the comparative Ct method. Experiments were repeated for at least three times with similar results. Tissues used for the study were artery, liver, lung, bursa cloacalis, heart, small intestine, peripheral blood mononuclear cells (PBMC), large intestine and kidney.

The level of TLR1 mRNA was higher in kidney, small intestine and PBMC (Fig. 7).
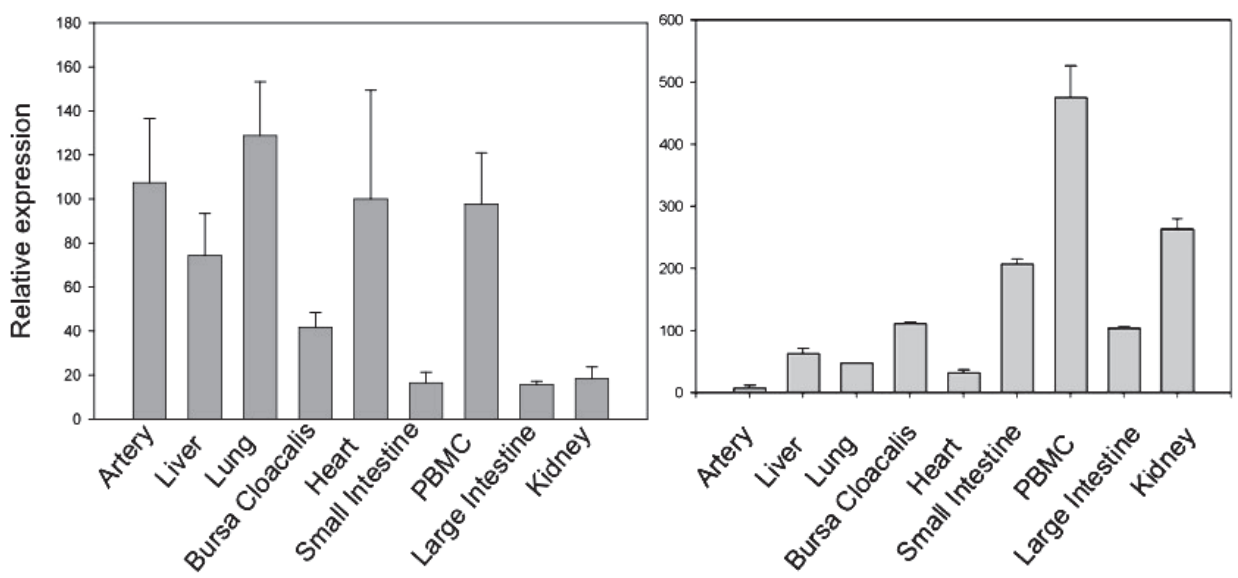

Fig. 7. Relative expression of TLR1 and IкBa mRNA transcripts in vulture cells and tissues.

Real time RT-PCR was used to examine the relative amount of TLR1 (right) and IkBa (left) transcripts in vulture cells and tissues. The data were normalised using the beta-actin gene and calculated by the delta Ct method.

Moderate vulture TLR1 mRNA levels were observed in Bursa cloacalis and large intestine, whereas the lowest TLR1 mRNA levels were found in liver, heart and artery (Fig. 6). It has 
been reported that the patterns of TLR tissue expression are variable, even among closely related species (Zarember \& Godowski 2002). Likewise, the intensity and the anatomic location of the innate immune response may vary considerably among species (Rehli, 2002). Consistent with its role in pathogen recognition and host defense, the tissue and cell expression pattern of vulture TLR1, as revealed by real time RT-PCR, correlated with vulture ability to respond to various pathogenic challenges. The expression of vulture TLR1 was higher in cells such as circulating PBMC and intestinal epithelial cells that are immediately accessible to microorganisms upon infection.

The analysis of the relative expression of IKBa mRNA transcripts, using real-time RT-PCR, demonstrated that vulture IKBa mRNAs were higher in lung, artery, heart, and in PBMC cells (Fig. 7), which was consistent with its role in numerous physiological processes. Interestingly, the expression of vulture IкBa mRNA was observed in tissues at which the lowest expression of vulture Toll-like receptor was found. This is consistent with the role of IKBa as inhibitor of the TLR-signalling pathway.

\section{Analysis of the evolutionary relationship of vulture TLR and IKBa}

The dendrogram of sequences was calculated based on the distance matrix that was generated from the pairwise scores and the phylogenetic trees were constructed based on the multiple alignment of the sequences using the PHYLIP (Phylogeny Inference Package) available at the expasy.org web page. All ClustalW phylogenetic calculations were based around the neighbor-joining method of Saitou and Nei (Saitou \& Nei, 1987).

For the analysis of the evolutionary relationship of vulture and other vertebrate TLR and IKBa, a phylogenetic tree was constructed with the TIR-domain sequences of human, macaque, bovine, pig, mouse, Japanese pufferfish and chicken TLR1. GenBank or swiss protein accessions numbers Q5WA51, Q706D2, Q6A0E8, Q59HI9, Q5H727 and Q5FWG5, respectively. The phylogenetic analysis of the TIR domain of vulture TLR1 revealed separate clustering of TLR1 from birds, fish, mouse and other mammals (Fig. 8B)

For the TLRs, it is assumed that the structure of the ectodomain has evolved more quickly than the structure of the TIR (Johnson, 2003). Similarly to other TLR receptors, the degree of homology of vulture TLR1 was higher in the transmembrane and cytoplasmic domains than in the extracellular domain. As expected, phylogenetic analysis of the TIR domains revealed separate clustering of TLR1 from birds, fish and mammals (Fig. 8B), suggesting independent evolution of the Toll family of proteins and of innate immunity (Beutler \& Rehli, 2002; Roach et al., 2005).

The unrooted trees were constructed by neighbor-joining analysis of an alignment of the ankirin repeats of IкBa sequences from vulture and other species (A) or the alignment of the TIR domains of TLR1 from vulture and other species (B). The branch lengths are proportional to the number of amino acid differences. GenBank or swiss protein accessions numbers of chicken (Gallus gallus), human (Homo sapiens), mouse (Mus musculus), rat (Rattus norvegicus), African frog (Xenopus laevis), cattle (Bos taurus), zebrafish (Danio rerio), Mongolian gerbil (Meriones unguiculatus), Rainbow trout (Oncorhynchus mykiss) and pig (Sus scrofa) sequences used for the phylogenetic tree were Q91974, P25963, Q08353, Q63746, Q1ET75, Q6DCW3, Q8WNW7, Q6K196, Q1ET75, Q8QFQ0 and Q9Z1E3, respectively. 


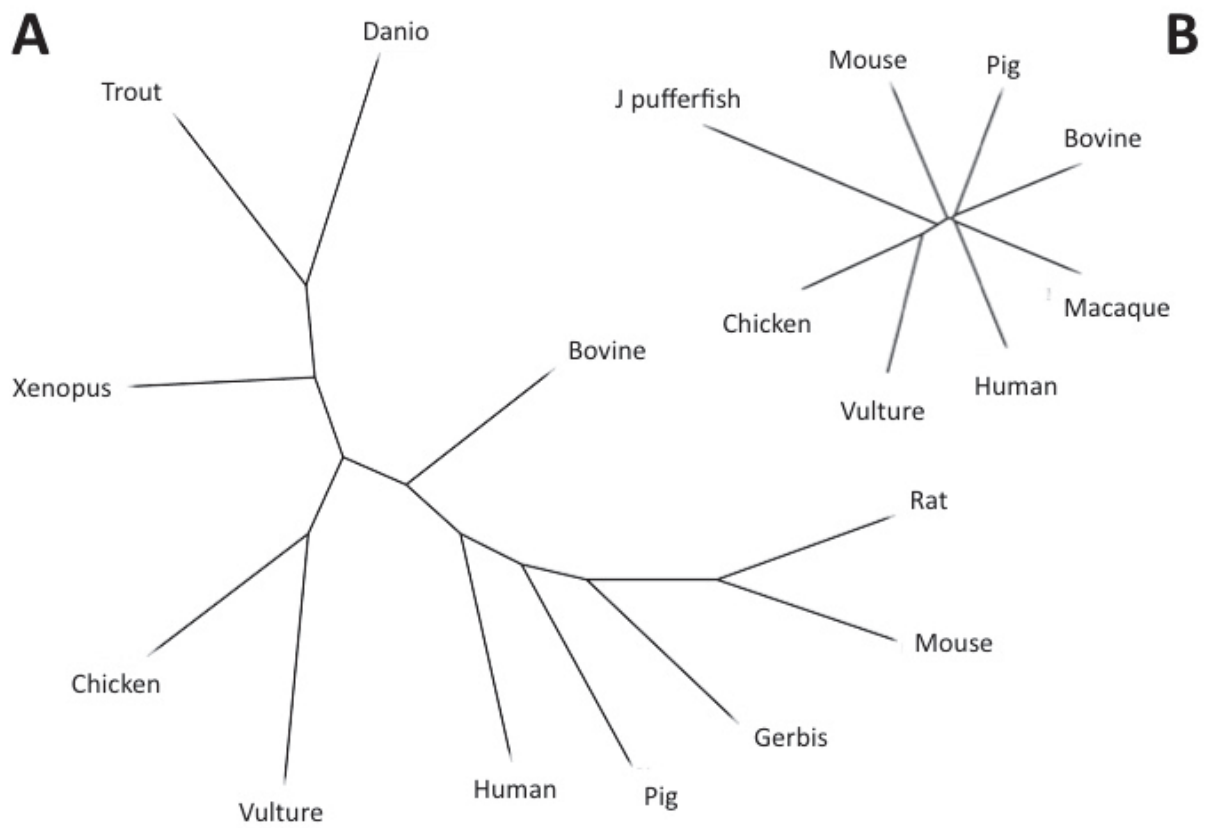

Fig. 8. Phylogenetic trees illustrating the relationship between TLR and IKBa sequences from vulture and other species.

For the analysis of the evolutionary relationship of vulture and other vertebrate IкBa, a phylogenetic tree was constructed with the sequences of chicken, human, mouse, rat, African frog, cattle, zebrafish, Mongolian gerbil, Rainbow trout and pig IкBa. The phylogenetic analysis of the ankyrin domain of vulture IKBa revealed separate clustering of ІкBa from rodents, fish and other species and the sequence of vulture IкBa clustered

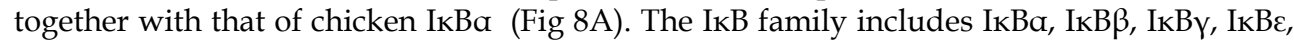

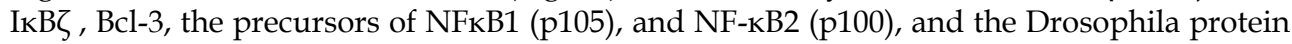
Cactus (Hayden et al., 2006; Karin \& Ben-Neriah, 2000; Totzke et al., 2006; Gilmore, 2006). Why multiple IкB proteins now exist in vertebrates has been a subject of great interest, and much effort has been expended on establishing the roles of individual members of this protein family in the regulation of NF-kB. The recent identification of a novel member of IкB

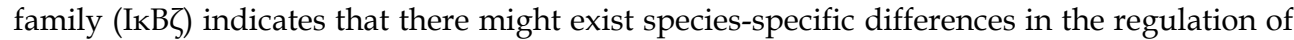
NF-kB (Totzke et al., 2006).

Evolutionarily, the IKB protein family is quite old, as members have been found in insects, birds and mammals (Ghosh \& Kopp, 1998). However, the finding that individual ankyrin repeats within each IкB molecule are more similar to corresponding ankyrin repeats in other ІкB family members, rather than to other ankyrin repeats within the same IкB, suggests that all IкB family members evolved from an ancestral IкB molecule (Huguet, et al., 1997).

Consistent with the hypothesis that all these factors evolved from a common ancestral RHDankyrin structure within a unique superfamily, explaining the specificities of interaction 
between the different Rel/NF-kappa B dimers and the various I kappa B inhibitors (Huguet, et al., 1997).

Recently, the presence of two IkappaB-like genes in Nematostella encoded by loci distinct from nf-kb suggested that a gene fusion event created the nfkb genes in insects and vertebrates (Sullivan et al., 2007). This is consistent with the hypothesis that interactions between transcription factors of the Rel members and members of the IKB gene family evolved to regulate genes mainly involved in immune inflammatory responses (Bonizzi \& Karin, 2004).

NF-kappaB represents an ancient, generalized signaling system that has been co-opted for immune system roles independently in vertebrate and insect lineages (Friedman \& Hughes, 2002). Therefore, while these proteins share a basic three-dimensional structure as predicted by their shared ankyrin repeat pattern and sequence, a possible evolutionary scenario based on this phylogenetic tree could be that subtle differences in the amino acid substitutions in the ankyrin repeats and flanking sequences occurred throughout evolution, which contributed to their specificity of interaction with various members of the Rel family.

\section{Conclusions}

In summary, the molecular cloning methods reported herein identified and characterized the vulture orthologues to TLR1 (CD281) and to IкBa, the first NF- $\mathrm{kB}$ pathway element from the griffon vulture G. fulvus. These results have implications for the understanding of the evolution of pathogen-host interactions. Particularly, these studies help to highlight a potentially important regulatory pathway for the study of the related functions in vulture immune system (Perez de la Lastra \& de la Fuente, 2007; 2008). Despite the overall structure of vulture TLR1 and expression pattern was similar to that of chicken, pig, cattle, human and mouse TLR, vulture TLR1 had differences in the length of the ectodomain, number and position of LRRs and N-glycosylation sites that makes vulture TLR1 structurally unique with possible functional implications.

Strong selective pressure for recognition of and response to pathogen-associated molecular patterns (PAMPs) has probably maintained a largely unchanged TLR signalling pathways in all vertebrates. The IкBa gene reported here expands our understanding of the immune regulatory pathways present in carrion birds that are in permanent contact with pathogens. Current investigations should focus on the cloning and characterization of other members of NF-kB signalling cascade and genes controlled by this signalling pathway. At this point it is difficult to understand the implications of the structural differences between vulture TLR1, chicken TLR1 and TLR1 in different mammalian species. A greater understanding of the functional capacity of non-mammalian TLRs and, particularly in carrion birds that are in permanent contact with pathogens, has implications for the understanding of the evolutionary pressures that defined the TLR repertoires in present day animals.

\section{Acknowledgements}

This work was supported by the Junta de Comunidades de Castilla-La Mancha (JCCM), project PII1I09-0243-4350. 


\section{References}

Aoki, T., et al., The ankyrin repeats but not the PEST-like sequences are required for signaldependent degradation of IkappaBalpha. Oncogene, 1996. 12(5): p. 1159-64.

Apanius, V., S.A. Temple, and M. Bale, Serum proteins of wild turkey vultures (Cathartes aura). Comp Biochem Physiol B, 1983. 76(4): p. 907-13.

Beutler, B. and M. Rehli, Evolution of the TIR, tolls and TLRs: functional inferences from computational biology. Curr Top Microbiol Immunol, 2002. 270: p. 1-21.

Bonizzi, G. and M. Karin, The two NF-kappaB activation pathways and their role in innate and adaptive immunity. Trends Immunol, 2004. 25(6): p. 280-8.

Brown, K., et al., The signal response of IkappaB alpha is regulated by transferable N- and C-terminal domains. Mol Cell Biol, 1997. 17(6): p. 3021-7.

Desterro, J.M., M.S. Rodriguez, and R.T. Hay, SUMO-1 modification of IkappaBalpha inhibits NF-kappaB activation. Mol Cell, 1998. 2(2): p. 233-9.

Friedman, R. and A.L. Hughes, Molecular evolution of the NF-kappaB signaling system. Immunogenetics, 2002. 53(10-11): p. 964-74.

Ghosh, S., M.J. May, and E.B. Kopp, NF-kappa B and Rel proteins: evolutionarily conserved mediators of immune responses. Annu Rev Immunol, 1998. 16: p. 225-60.

Gilmore, T.D., Introduction to NF-kappaB: players, pathways, perspectives. Oncogene, 2006. 25(51): p. 6680-4.

Good, L.F., et al., Multiple structural domains within I kappa B alpha are required for its inducible degradation by both cytokines and phosphatase inhibitors. Biochem Biophys Res Commun, 1996. 223(1): p. 123-8.

Hayden, M.S., A.P. West, and S. Ghosh, NF-kappaB and the immune response. Oncogene, 2006. 25(51): p. 6758-80.

Hopkins, P.A. and S. Sriskandan, Mammalian Toll-like receptors: to immunity and beyond. Clin Exp Immunol, 2005. 140(3): p. 395-407.

Houston, D.C. and J.E. Cooper, The digestive tract of the whiteback griffon vulture and its role in disease transmission among wild ungulates. J Wildl Dis, 1975. 11(3): p. 30613.

Huguet, C., P. Crepieux, and V. Laudet, Rel/NF-kappa B transcription factors and I kappa B inhibitors: evolution from a unique common ancestor. Oncogene, 1997. 15(24): p. 2965-74.

Jaffray, E., K.M. Wood, and R.T. Hay, Domain organization of I kappa B alpha and sites of interaction with NF-kappa B p65. Mol Cell Biol, 1995. 15(4): p. 2166-72.

Johnson, G.B., et al., Evolutionary clues to the functions of the Toll-like family as surveillance receptors. Trends Immunol, 2003. 24(1): p. 19-24.

Karin, M. and Y. Ben-Neriah, Phosphorylation meets ubiquitination: the control of NF[kappa]B activity. Annu Rev Immunol, 2000. 18: p. 621-63.

Krishnan, V.A., et al., Structure and regulation of the gene encoding avian inhibitor of nuclear factor kappa B-alpha. Gene, 1995. 166(2): p. 261-6.

Luque, I. and C. Gelinas, Distinct domains of IkappaBalpha regulate c-Rel in the cytoplasm and in the nucleus. Mol Cell Biol, 1998. 18(3): p. 1213-24.

Luque, I., et al., N-terminal determinants of I kappa B alpha necessary for the cytoplasmic regulation of c-Rel. Oncogene, 2000. 19(9): p. 1239-44.

Mabb, A.M. and S. Miyamoto, SUMO and NF-kappaB ties. Cell Mol Life Sci, 2007. 64(15): p. 1979-96. 
Ohishi, I., et al., Antibodies to Clostridium botulinum toxins in free-living birds and mammals. J Wildl Dis, 1979. 15(1): p. 3-9.

Perez de la Lastra, J.M. and J. de la Fuente, Molecular cloning and characterisation of the griffon vulture (Gyps fulvus) toll-like receptor 1. Dev Comp Immunol, 2007. 31(5): p. 511-9.

Perez de la Lastra, J.M. and J. de la Fuente, Molecular cloning and characterisation of a homologue of the alpha inhibitor of NF-kB in the griffon vulture (Gyps fulvus). Vet Immunol Immunopathol, 2008. 122: p. 318-25

Pons, J., et al., Structural studies on 24P-IkappaBalpha peptide derived from a human IkappaB-alpha protein related to the inhibition of the activity of the transcription factor NF-kappaB. Biochemistry, 2007. 46(11): p. 2958-72.

Rehli, M., Of mice and men: species variations of Toll-like receptor expression. Trends Immunol, 2002. 23(8): p. 375-8.

Roach, J.C., et al., The evolution of vertebrate Toll-like receptors. Proc Natl Acad Sci U S A, 2005. 102(27): p. 9577-82.

Saitou, N. and M. Nei, The neighbor-joining method: a new method for reconstructing phylogenetic trees. Mol Biol Evol, 1987. 4(4): p. 406-25.

Shumway, S.D., M. Maki, and S. Miyamoto, The PEST domain of IkappaBalpha is necessary and sufficient for in vitro degradation by mu-calpain. J Biol Chem, 1999. 274(43): p. 30874-81.

Sullivan, J.C., et al., Rel homology domain-containing transcription factors in the cnidarian Nematostella vectensis. Dev Genes Evol, 2007. 217(1): p. 63-72.

Takeda, K. and S. Akira, Toll-like receptors in innate immunity. Int Immunol, 2005. 17(1): p. $1-14$.

Takeda, K., Evolution and integration of innate immune recognition systems: the Toll-like receptors. J Endotoxin Res, 2005. 11(1): p. 51-5.

Totzke, G., et al., A novel member of the IkappaB family, human IkappaB-zeta, inhibits transactivation of p65 and its DNA binding. J Biol Chem, 2006. 281(18): p. 12645-54.

Weber, A.N., M.A. Morse, and N.J. Gay, Four N-linked glycosylation sites in human toll-like receptor 2 cooperate to direct efficient biosynthesis and secretion. J Biol Chem, 2004. 279(33): p. 34589-94.

Yilmaz, A., et al., Identification and sequence analysis of chicken Toll-like receptors. Immunogenetics, 2005. 56(10): p. 743-53.

Zarember, K.A. and P.J. Godowski, Tissue expression of human Toll-like receptors and differential regulation of Toll-like receptor mRNAs in leukocytes in response to microbes, their products, and cytokines. J Immunol, 2002. 168(2): p. 554-61. 


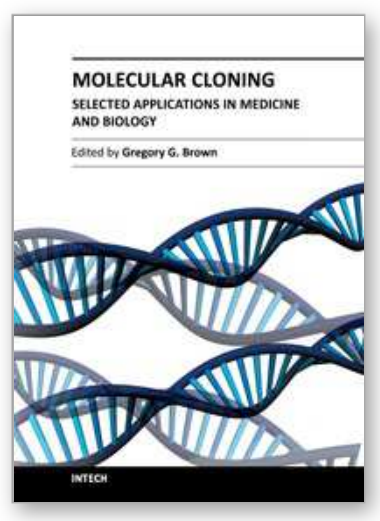

\author{
Molecular Cloning - Selected Applications in Medicine and Biology \\ Edited by Prof. Gregory Brown
}

ISBN 978-953-307-398-9

Hard cover, 324 pages

Publisher InTech

Published online 12, October, 2011

Published in print edition October, 2011

The development of molecular cloning technology in the early 1970 s created a revolution in the biological and biomedical sciences that extends to this day. The contributions in this book provide the reader with a perspective on how pervasive the applications of molecular cloning have become. The contributions are organized in sections based on application, and range from cancer biology and immunology to plant and evolutionary biology. The chapters also cover a wide range of technical approaches, such as positional cloning and cutting edge tools for recombinant protein expression. This book should appeal to many researchers, who should find its information useful for advancing their fields.

\title{
How to reference
}

In order to correctly reference this scholarly work, feel free to copy and paste the following:

Elena Crespo, José de la Fuente and José M. Pérez de la Lastra (2011). Identification of Molecules Involved in the Vulture Immune Sensing of Pathogens by Molecular Cloning, Molecular Cloning - Selected Applications in Medicine and Biology, Prof. Gregory Brown (Ed.), ISBN: 978-953-307-398-9, InTech, Available from: http://www.intechopen.com/books/molecular-cloning-selected-applications-in-medicine-andbiology/identification-of-molecules-involved-in-the-vulture-immune-sensing-of-pathogens-by-molecular-cloning

\section{INTECH}

open science | open minds

\section{InTech Europe}

University Campus STeP Ri

Slavka Krautzeka 83/A

51000 Rijeka, Croatia

Phone: +385 (51) 770447

Fax: +385 (51) 686166

www.intechopen.com

\section{InTech China}

Unit 405, Office Block, Hotel Equatorial Shanghai

No.65, Yan An Road (West), Shanghai, 200040, China

中国上海市延安西路65号上海国际贵都大饭店办公楼405单元

Phone: +86-21-62489820

Fax: +86-21-62489821 
(C) 2011 The Author(s). Licensee IntechOpen. This is an open access article distributed under the terms of the Creative Commons Attribution 3.0 License, which permits unrestricted use, distribution, and reproduction in any medium, provided the original work is properly cited. 